Article

\title{
Reef Structural Complexity Influences Fish Community Metrics on a Remote Oceanic Island: Serranilla Island, Seaflower Biosphere Reserve, Colombia
}

\author{
Diana Castaño ${ }^{1}$, Diana Morales-de-Anda ${ }^{2, *} \mathbb{C}$, Julián Prato ${ }^{1,3}$, Amílcar Leví Cupul-Magaña ${ }^{2}$, \\ Johanna Paola Echeverry ${ }^{4}$ and Adriana Santos-Martínez ${ }^{1,3}$ \\ 1 Universidad Nacional de Colombia-Sede Caribe, Archipiélago de San Andrés, Providencia y Santa Catalina, \\ San Andrés Isla 880008, Colombia; dcastano@unal.edu.co (D.C.); jprato@unal.edu.co (J.P.); \\ asantosma@unal.edu.co (A.S.-M.) \\ 2 Laboratorio de Ecología Marina, Centro de Investigaciones Costeras, Centro Universitario de la Costa, \\ Universidad de Guadalajara, Puerto Vallarta 48280, Mexico; amilcar.cupul@gmail.com \\ 3 Corporation Center of Excellence in Marine Science-CEMarin, Bogotá 111311, Colombia \\ 4 Dirección General Marítima, Subdirección de Desarrollo Marítimo, Infraestructura de Datos Espaciales, \\ Marítima, Fluvial y Costera, Bogotá 111321, Colombia; jpecheverryh@unal.edu.co \\ * Correspondence: dianamorales9009@gmail.com; Tel.: +52-322-213-7717
}

\section{check for}

updates

Citation: Castaño, D.; Morales-deAnda, D.; Prato, J.; Cupul-Magaña, A.L.; Echeverry, J.P.; Santos-Martínez, A. Reef Structural Complexity Influences Fish Community Metrics on a Remote Oceanic Island: Serranilla Island, Seaflower Biosphere Reserve, Colombia. Oceans 2021, 2, 611-623. https://doi.org/10.3390/ oceans2030034

Academic Editor: Rupert Ormond

Received: 30 October 2020

Accepted: 18 August 2021

Published: 3 September 2021

Publisher's Note: MDPI stays neutral with regard to jurisdictional claims in published maps and institutional affiliations.

Copyright: (c) 2021 by the authors. Licensee MDPI, Basel, Switzerland. This article is an open access article distributed under the terms and conditions of the Creative Commons Attribution (CC BY) license (https:// creativecommons.org/licenses/by/ $4.0 /)$.
Abstract: Serranilla is a protected island of the Seaflower Biosphere Reserve, far from dense human population. These characteristics could help sustain structurally complex coral reefs, often associated with higher biodiversity, abundance, and biomass of reef-associated organisms, including reef fish. However, the multiple threats present in Serranilla, including intense illegal fishing, can impact coral ecosystems generally and also specific key groups, such as the parrotfish, in particular. During the "Seaflower Research Expedition 2017", we assessed how structural habitat complexity influences reef fish assemblages. In addition, we explored differences in parrotfish species (family: Scaridae) between Serranilla and San Andrés, the most populated island in the Archipelago. On Serranilla, we found that habitat structure, rugosity, and coral cover accounted for up to $66 \%$ of variation in reef fish diversity, abundance, and biomass, with values being higher on more complex reefs. Parrotfish species differed between the islands, with larger species supporting higher biomasses at Serranilla, by comparison with San Andrés; however, the abundance, biomass, and lengths of parrotfish species were low in both areas compared with those reported from other protected Caribbean reefs. Our study indicates that despite the evident relationship between structurally complex habitats and reef fish, other threats in Serranilla could be affecting parrotfish populations, such as illegal fishing, a widespread activity in the area.

Keywords: structural complexity; coral reef; Caribbean; biodiversity; overfishing; parrotfish; Seaflower Biosphere Reserve

\section{Introduction}

Coral reefs are widely recognized as one of the most diverse marine ecosystems, providing essential habitats for numerous species; although coral reefs cover only $0.02 \%$ of the ocean's surface, they are believed to harbor nearly 30\% of all known marine species [1-4]. Reef ecosystems provide multiple ecosystem services [5-7], including coastal protection [8,9] and the provision of food and livelihoods through fishing activities [10]. However, in recent decades, coral reef ecosystems worldwide have been facing degradation due to multiple environmental and human stressors [11,12]. Currently, $\sim 60 \%$ of the world's coral reefs are considered to be threatened [13]. In the Caribbean, by 2003, at least $80 \%$ of the coral cover registered in the 1970s was lost [14,15], while in the Atlantic, 75\% of coral reefs are considered at risk [12]. This loss of coral cover has often produced a decline in the reef's 
structural complexity, affecting associated organisms including reef fish [16]. The replacement of structurally complex coral species represents a more silent problem [17]; branching coral species have often been replaced by "weedy" species of coral, which display less rugosity and tridimensional structure, so that even if coral cover recovers, the system may possess lower structural complexity [18]. On Caribbean reefs, a considerable loss of species that provide high structural complexity, such as Acropora palmata, A. cervicornis, and Montastrea cavernosa, was evident from the 1970s, aggravated by mass coral mortality as the result of reef erosion caused by the sea urchin Diadema antillarum through an increasing prevalence of coral disease and by coral bleaching events $[17,19]$. Such declines in structural complexity on coral reefs can have negative consequences, including loss of ecological function, biodiversity, and ecosystem services $[2,7,20]$. However, it is essential to identify, beyond structural complexity, other features of reef ecosystems which are involved in the maintenance of essential functions and processes [21].

Herbivory is one of the key processes in coral reefs that can prevent the overgrowth of corals by algae through food web control over turf and macroalgae [11,22,23]. Herbivorous fishes are considered essential to reef ecosystems' health, especially after the radical decline in the Caribbean of other large herbivores, including sea turtles and manatees [24], and previously dense populations of D. antillarum [25]. Among herbivorous fish, parrotfishes (Family: Scaridae) are considered important in promoting the recovery of coral reefs after disturbances (i.e., bleaching events or storms) and in preventing phase shifts from coral to algal-dominated communities [16,26-28]. Notably, in the Caribbean, some Marine Protected Areas (MPAs) have been found to possess high parrotfish biomass, low macroalgae cover, and high coral cover, with abundant coral recruits [28,29]. However, parrotfish are high among the fisheries' target species, crucial for most Caribbean economies [23]. Fishing has been found to deplete many coral reef fish species, promoting reef degradation [30-32].

The Seaflower Biosphere Reserve (Seaflower BR) is one of the largest protected areas in the Caribbean, covering 180,000 $\mathrm{km}^{2}$ and incorporating a large percentage of Colombia's coral reefs [33]. Although the Seaflower BR is an extensive MPA and experiences oceanic conditions that might be expected to support pristine coral reefs with high structural complexity and biodiversity, the archipelago islands nevertheless experience illegal fishing, including overfishing, together with other anthropogenic pressures [23]. Of the nine islands in the archipelago, Serranilla, northwest of the Seaflower BR, is furthest from the mainland and it was here that recent research efforts were focused during the "Seaflower Research Expedition 2017". We designed our study to evaluate the status of fish assemblages in relation to reef habitat structural complexity, paying particular attention to comparing the parrotfish species of Serranilla from that found at San Andrés.

\section{Materials and Methods}

\subsection{Study Site}

Serranilla island $\left(15^{\circ} 50^{\prime} \mathrm{N}, 079^{\circ} 50^{\prime} \mathrm{W}\right)$, officially named Isla Cayos de Serranilla, is located at the northwest end of the Seaflower Biosphere Reserve (Figure 1). Seaflower BR, with an area of $180,000 \mathrm{~km}^{2}$, was declared as a Biosphere Reserve by UNESCO in 2000; within this larger area, the Colombian Government designated $65,000 \mathrm{~km}^{2}$ as Marine Protected Area in 2005 [33]. In fact, Serranilla is not a single island, but a reef complex formed on a submarine mountain, on which emerged cays are scattered. The principal cay is Beacon Cay, located in the south east of the complex (Figure 1c). The underwater seascape consists of a carbonate platform with reef habitats such as reef crests, coral patches, sand flats, hardground areas, and also seagrass beds [34]. This island is located a long way $(>400 \mathrm{~km})$ from the most populated island of the archipelago, San Andrés, and lies only $320 \mathrm{~km}$ south of Jamaica (Figure 1a,b; Figure S1). San Andrés, in contrast, has a terrestrial area of $27 \mathrm{~km}^{2}$, with a maximum length of $12.6 \mathrm{~km}$ and maximum width of $3 \mathrm{~km}$. On the west side of San Andrés there is a submarine hard bottom platform extending seawards for 200-500 m, and a mainly continuous rocky shore, but no barrier reef. On the east side of the island, the platform extends seawards for more than $2 \mathrm{~km}$ with some soft sand bottom 
areas, small coral patches, mangroves, and sandy beaches on the coast, and, at the east edge of the northern part, a discontinuous barrier reefs of about $9 \mathrm{~km}$ in length [33].

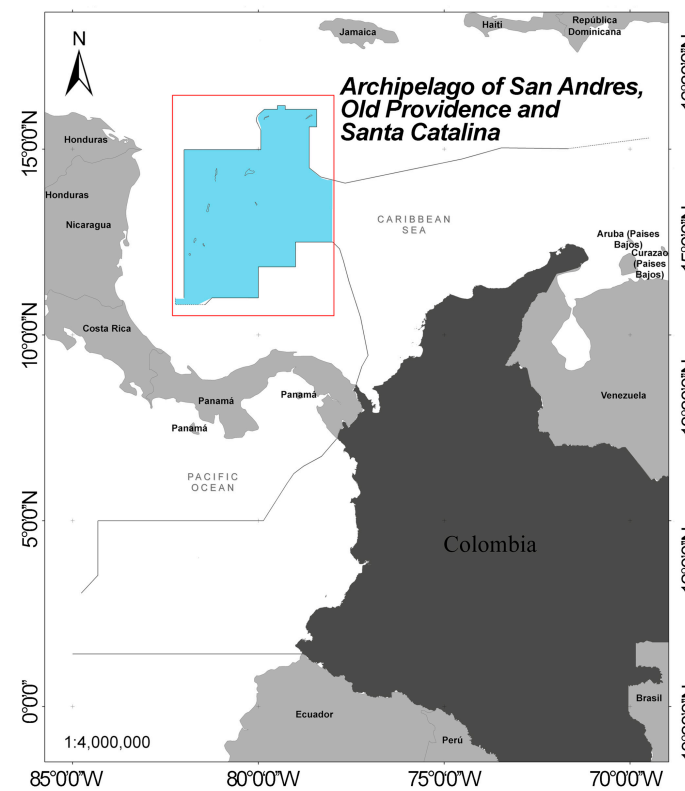

(a)

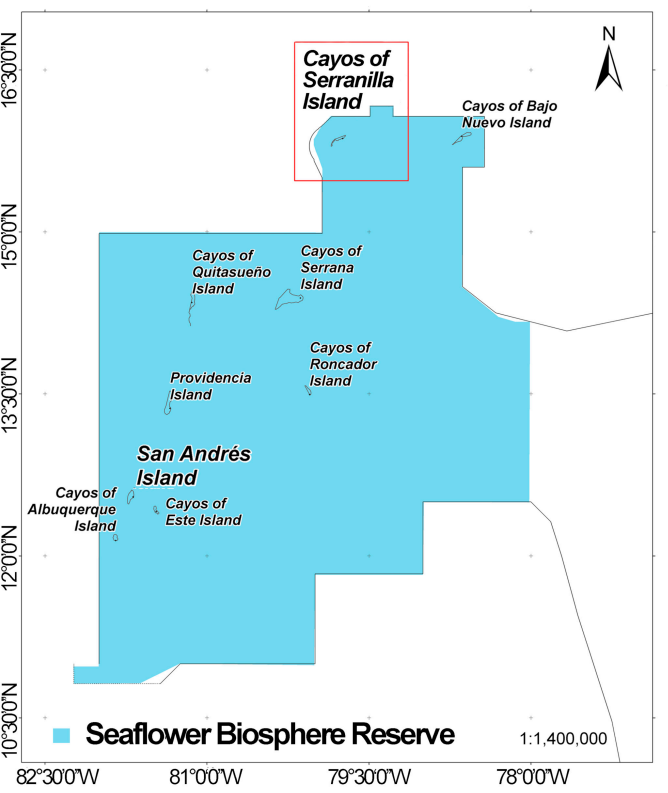

(b)

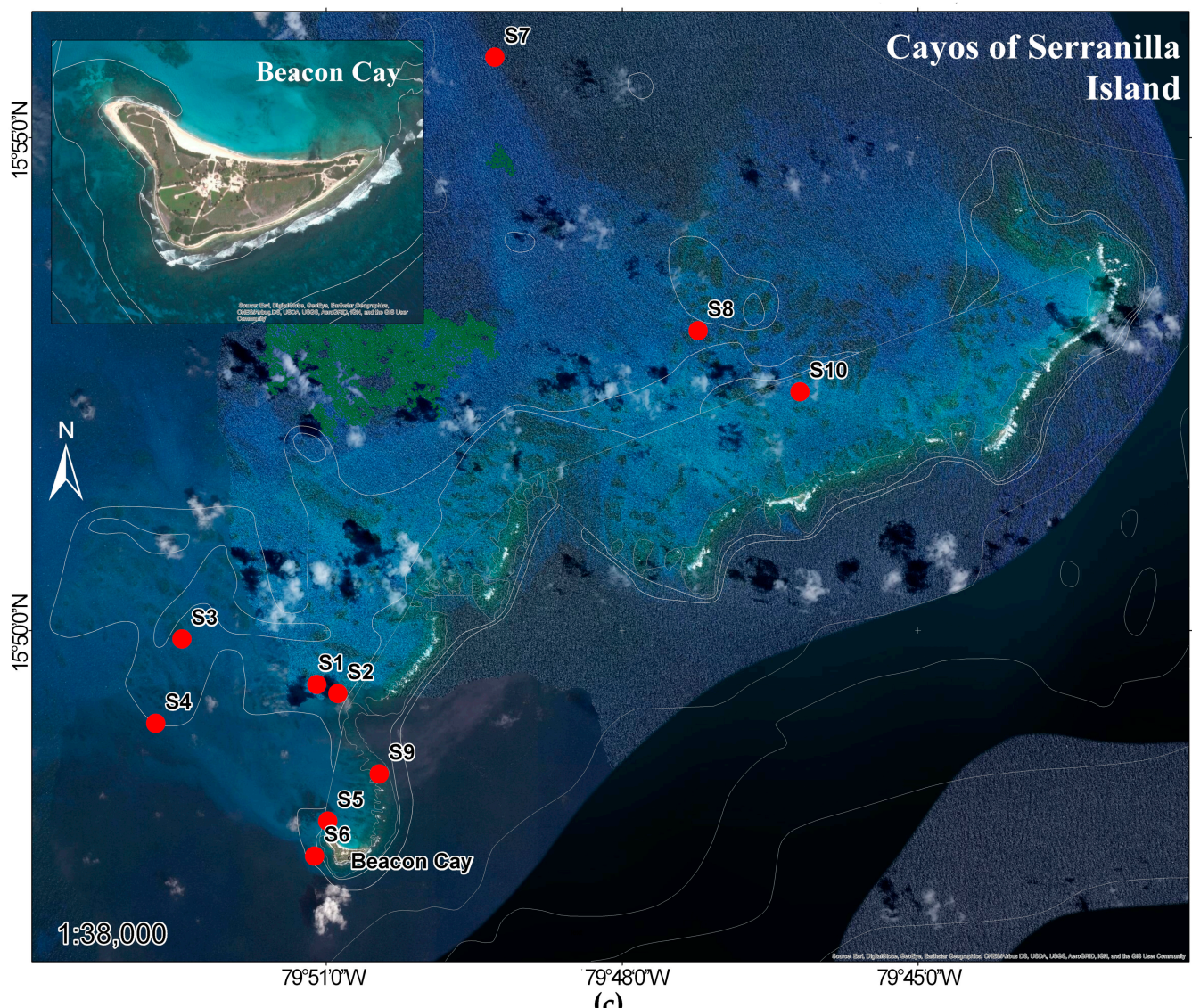

(c)

Figure 1. Maps showing the position of the study area: (a) the location of the Seaflower BR in the south west of the Caribbean, (b) map of the Seaflower BR showing the San Andres archipelago, including San Andrés, Old Providence, and Serranilla island, and (c) the locations of the survey sites at Serranilla (red points: S1-S10) together with (inserted) an aerial image of Beacon Cay, the largest cay on Serranilla (top left). 


\subsection{Data Collection}

The surveys were conducted at ten sites at Serranilla during the "Seaflower Research Expedition 2017". Ten sites were selected to capture the heterogeneity of Serranilla (Table S1). At each site, habitat structure (benthic components and rugosity) and fish assemblage structure and composition were assessed using underwater visual census (UVC) techniques conducted by a paired-diver team along $50 \mathrm{~m} \times 2 \mathrm{~m}$ belt transects ( $\mathrm{n}$ per site $=2$ or 3). On each transect, the fish species, abundance, and visual estimated size per individual (interval length) were recorded by the first diver, following established sampling methodologies [35-37]. To highlight the specific relationships of the key fish family of parrotfish (Scaridae) with habitat, the abundance of parrotfish according to the size was also calculated; we distinguished large species $(>50.1 \mathrm{~cm}$ total length) and small species ( $<50 \mathrm{~cm}$ total length) based on available values from FishBase [38]. Valid species names were verified, according to Fricke et al. [39].

Habitat structure was evaluated as a combination of the percentage cover of the main benthic components and of reef rugosity. To characterize the coral community, we selected the percentage cover of five morpho-functional benthic groups: branching corals, brain corals, submassive corals, spherical corals, and algae. The variables were recorded with a video camera that was held $0.4 \mathrm{~m}$ above the seabed while being moved along each of the 50 transects. From each such video transect, 40 frames were selected, and 50 points in each frame were sampled to estimate the percentage of the benthic groups. Rugosity was estimated with the rugosity index (RI), obtained using the chain-link method [40]. Within each belt transect, the second diver laid down a $10 \mathrm{~m}$ chain over the seabed closely following the substrate contour and then measured the linear distance occupied by the chain. This was done three times within each transect. RI was then calculated as $\mathrm{RI}=1-\mathrm{d} / \mathrm{L}$, where $\mathrm{d}$ is the horizontal distance covered by the chain, and $\mathrm{L}$ is the chain's true (i.e., stretched) length. This method is quick, objective, and highly replicable [36].

Fish data for San Andrés were obtained during the same sampling period as the Serranilla surveys (September 2017). Data were collected from transects at three sites on the west side (Luna Verde, Wild Life and Bajo Bonito) and one on the east side (Bahía Honda) of the island. Fish species, abundance, and estimated fish size in San Andrés were recorded following the same UVC described above for Serranilla. To compare parrotfish, we selected 12 transects for each location (Serranilla and San Andrés), all placed parallel to the coast, with comparable values of RI (0.19-0.49).

\subsection{Analysis}

We used two approaches to analyze the reef fish assemblages at Serranilla and San Andrés. The first approach aimed to characterize the relationship of fish assemblages to habitat structure. The second focused on the parrotfish assemblage, evaluating differences between Serranilla and San Andrés.

\subsubsection{Relationship of Reef Fish Assemblages to Habitat Structure}

For each transect, we estimated diversity, abundance, and biomass. Biomass $\left(\mathrm{g} \mathrm{m}^{-2}\right)$ was calculated using the allometric weight equation:

$$
\mathrm{W}=\mathrm{a} \mathrm{L}^{\mathrm{b}}
$$

where $L$ is the weighted mean of the estimated length for each species per transect, and a and $b$ are the constants of length-weight obtained from FishBase [38].

We evaluated diversity using Hill's effective number of species of order 0,1 , and 2 [41], where ${ }^{0} \mathrm{D}$ is species richness, ${ }^{1} \mathrm{D}$ considers all species and their abundance, ${ }^{2} \mathrm{D}$ reflects the most abundant species, and ${ }^{2 / 1} \mathrm{D}$ reflects their evenness. To explore the relationships of reef fish assemblages to habitat, we performed multiple linear regressions of fish assemblage measures against the main explanatory variables that define habitat structure (benthic cover and rugosity). The preferred models were selected based on the lowest values of Akaike's 
Information Criterion (AICc). The models' variables included the average parameters of the models with $<2 \Delta \mathrm{AICc}$ [42]. The $p$-value and adjusted $\mathrm{R}^{2}$ of the model with all the explanatory variables and the selected variables were reported. For each model, the validity of the linear models was examined with the normality of the residuals [43].

\subsubsection{Differences in Parrotfish Assemblages between Islands (Serranilla and San Andrés)}

We evaluated variation in the metrics $\left({ }^{0} \mathrm{D}\right.$, biomass, and abundance) and composition (abundance and biomass) of the Scaridae species present between the two islands, Serranilla and San Andrés. We also examined the mean sizes observed for each species at Serranilla and contrasted these with the available information about common and maximum size obtained from FishBase [38].

Two ANOVAs based on permutations $(10,000)$ were performed to test the differences in biomass and abundance using Euclidean matrices from fourth-root transformed data. We used a model with one factor:

$$
\mathrm{Y}_{\mathrm{ij}}=\mu+\text { Island }_{\mathrm{i}}+\mathrm{e}_{\mathrm{ij}}
$$

where $\mu$ is the general mean; Island $\mathrm{i}_{\mathrm{i}}$ is the factor with two levels (Serranilla and San Andrés) and 12 replicates per site, and $\mathrm{e}_{\mathrm{ij}}$ is the associated error.

Two permutational multivariate analyses of variance (PERMANOVA) were performed to assess parrotfish assemblage composition differences in biomass and abundance. We used the previous ANOVA model and verified the homogeneity of dispersion with the PERMDISP test and non-metric multidimensional scaling (NMDS) [44]. Similarity percentage analysis (SIMPER) were used to detect the parrotfish responsible for the dissimilarities between the islands. We plotted in the NMDS the small and large parrotfish abundance and biomass to visualize the differences in composition. For PERMANOVA, PERMDISP, SIMPER, and NMDS, we used a Bray-Curtis similarity matrix with a fourth root transformed data. Statistical analyses were performed in $R$ and Primer v6.1 PERMANOVA+ [45,46], and plots for SIMPER results generated in SigmaPlot v11 software.

\section{Results}

A total of 8137 individual fish belonging to 68 species and 22 families were recorded across the sites on Serranilla. The families represented by the most species were: Scaridae (12 spp), Pomacentridae (9 spp), and Labridae (7 spp). Three wrasses (Labridae) were the most abundant species, representing $50 \%$ of the total fish abundance: Halichoeres bivittatus, H. garnoti, and Thalassoma bifasciatum. However, because of the larger sizes of individuals, the highest mean biomasses were represented by Haemulon album, Melichthys niger, and Mulloidichthys martinicus, which together contributed $>30 \%$ of the total biomass (Table S2).

\subsection{Relationship of Reef Fish Assemblages to Habitat Structure}

The results of the multiple linear regressions supported the interpretation that at Serranilla overall fish abundance, biomass, and diversity were related to habitat structure (Table 1). Up to $66 \%$ of the variation in measures of reef fish assemblage structure was significantly explained, except for variation in biomass and evenness. Among all the measured explanatory variables, rugosity, and coral cover of branching and brain corals were most often significant. Of the diversity indices, species richness $\left({ }^{0} \mathrm{D}\right)$ was the measure with the greatest percentage of variation described (59\%), in that case by only one variable (rugosity). In contrast, $66 \%$ of variation in the abundance of small parrotfish species was explained by the combination of all six measures of habitat structure (Table 1). 
Table 1. Habitat structure drivers of reef fish diversity and abundance at Serranilla; regressions of fish assemblage measures against reef habitat measures. The results shown within each pair of lines are for (upper line) linear models using all potential explanatory variables and (lower line) for the best fit model selected using AICc criteria. $p$-values are shown for the adjusted $R^{2}$ estimates as well as for the entire model.

\begin{tabular}{|c|c|c|c|c|c|c|c|c|c|}
\hline \multirow{2}{*}{ Indices } & \multirow{2}{*}{$\begin{array}{l}\text { Num. of } \\
\text { Variables }\end{array}$} & \multicolumn{6}{|c|}{$p$-Values of Variables in the Model } & \multicolumn{2}{|c|}{ Total Model } \\
\hline & & Rugo & Bran & Sphe & Brain & Subm & Algae & $\mathbf{R}_{\text {adj }}$ & $p$-Value \\
\hline \multirow[b]{2}{*}{ Biomass } & All & 0.46 & 0.81 & 0.87 & 0.41 & 0.71 & 0.16 & 0.364 & 0.066 \\
\hline & 5 & 0.54 & 0.34 & 0.37 & & 0.87 & 0.22 & 0.378 & 0.427 \\
\hline \multirow[b]{2}{*}{ Abundance } & All & 0.001 & 0.94 & 0.49 & 0.59 & 0.09 & 0.51 & 0.558 & 0.01 \\
\hline & 3 & 0.14 & & 0.56 & & 0.41 & & 0.385 & 0.016 \\
\hline \multirow{2}{*}{${ }^{0} \mathrm{D}$} & All & 0.03 & 0.9 & 0.81 & 0.7 & 0.94 & 0.71 & 0.463 & 0.028 \\
\hline & 1 & $<0.001$ & & & & & & 0.592 & $<0.001$ \\
\hline \multirow{2}{*}{${ }^{1} \mathrm{D}$} & All & 0.3 & 0.83 & 0.71 & 0.98 & 0.52 & 0.14 & 0.389 & 0.034 \\
\hline & 3 & 0.23 & & & & 0.39 & 0.06 & 0.502 & 0.003 \\
\hline \multirow{2}{*}{${ }^{2} \mathrm{D}$} & All & 0.36 & 0.56 & 0.54 & 0.92 & 0.51 & 0.07 & 0.357 & 0.07 \\
\hline & 3 & 0.02 & & & & 0.73 & 0.01 & 0.459 & 0.006 \\
\hline \multirow{2}{*}{${ }^{2 / 1} \mathrm{D}$} & All & 0.22 & 0.23 & 0.24 & 0.49 & 0.64 & 0.12 & 0.237 & 0.156 \\
\hline & 4 & 0.16 & 0.6 & & & 0.48 & 0.26 & 0.261 & 0.083 \\
\hline \multirow{2}{*}{ Small parrotfish abundance } & All & 0.28 & $<0.01$ & 0.12 & $<0.01$ & 0.082 & 0.83 & 0.661 & 0.002 \\
\hline & 4 & 0.53 & $<0.01$ & & $<0.01$ & 0.49 & & 0.408 & 0.006 \\
\hline \multirow{2}{*}{ Large parrotfish abundance } & All & 0.02 & 0.15 & 0.11 & 0.77 & 0.23 & 0.61 & 0.376 & 0.06 \\
\hline & 2 & $<0.01$ & & 0.22 & & & & 0.408 & 0.006 \\
\hline
\end{tabular}

Abbreviations. Rugo: rugosity; Bran: branching coral; Subm: submassive coral; Sphe: spherical coral; Brain: brain coral.

\subsection{Parrotfish Differences between Islands (Serranilla and San Andrés)}

We recorded 11 parrotfish species present within one or both of the two islands, 11 on Serranilla and six on San Andrés (Scarus coelestinus, S. coeruleus, S. guacamaia, S. iseri, S. taeniopterus, S. vetula, Sparisoma atomarium, S. aurofrenatum, S. chrysopterum, S. rubripinne, S. viride). S. viride was the species with both the highest abundance and biomass on Serranilla, and on San Andrés, S. taeniopterus and S. aurofrenatum had the highest abundance and biomass, respectively (Table S3). Comparison of metrics between Serranilla and San Andrés showed that there was no statistical difference in overall abundance (Pseudo- $F=2.137$, $p=0.146)$ or species richness per transect $\left({ }^{0} \mathrm{D}\right.$; Pseudo- $\left.F=2.057, p=0.105\right)$ between the two island areas, but there was a statistically significant difference in parrotfish biomass per transect (Pseudo- $F=4.637 ; p=0.040$ ).

Nevertheless, parrotfish assemblage composition did appear significantly different between the two islands when examined both in terms of abundance (Pseudo- $F=16.031$, $p<0.001$ ) and in terms of biomass (Pseudo- $F=12.170, p<0.001$ ) with NMDS plots; these showed, in relation to both measures, a strong spatial segregation between sites on the two islands and a notably higher dispersion among the Serranilla sites (Figure 2a,b). As shown by the sizes of the bubbles, at Serranilla, most of the parrotfish contributing to abundance and biomass were larger species, whereas at San Andrés these were mainly small-size parrotfish (Figure 2c-f).

The SIMPER analysis showed that just three species were responsible for $>50 \%$ of island dissimilarity, two of which had higher abundance and biomass in San Andrés (S. taeniopterus and S. aurofrenatum), and a third which had a considerably higher abundance in Serranilla (S. viride) (Figure 3; Table S4). Overall, the mean parrotfish size of each species was considerably smaller than the common and maximum lengths reported in FishBase (Figure S2). 
(a)

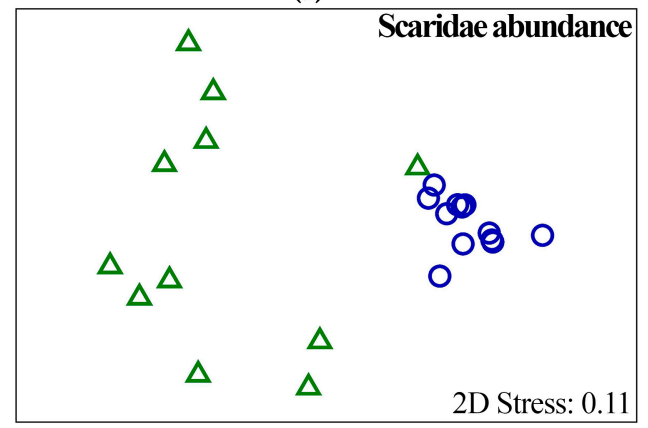

(c)

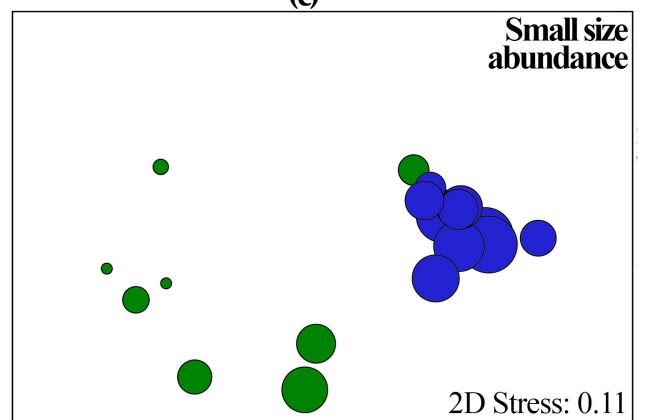

(e) (b)

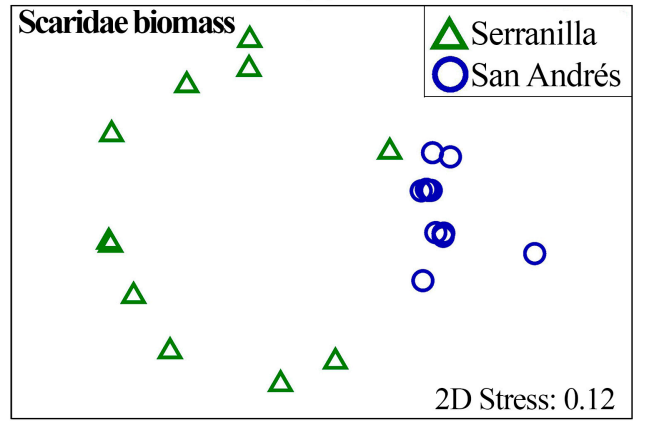

(d)

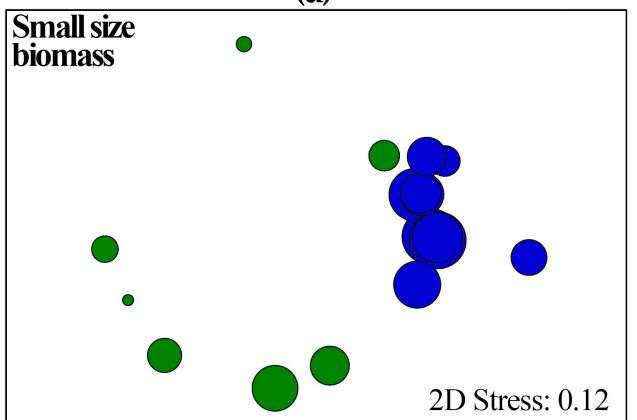

2D Stress: 0.12

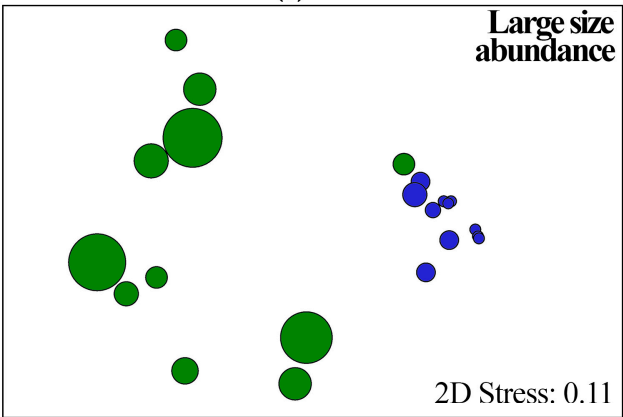

Abundance

3

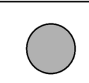

12
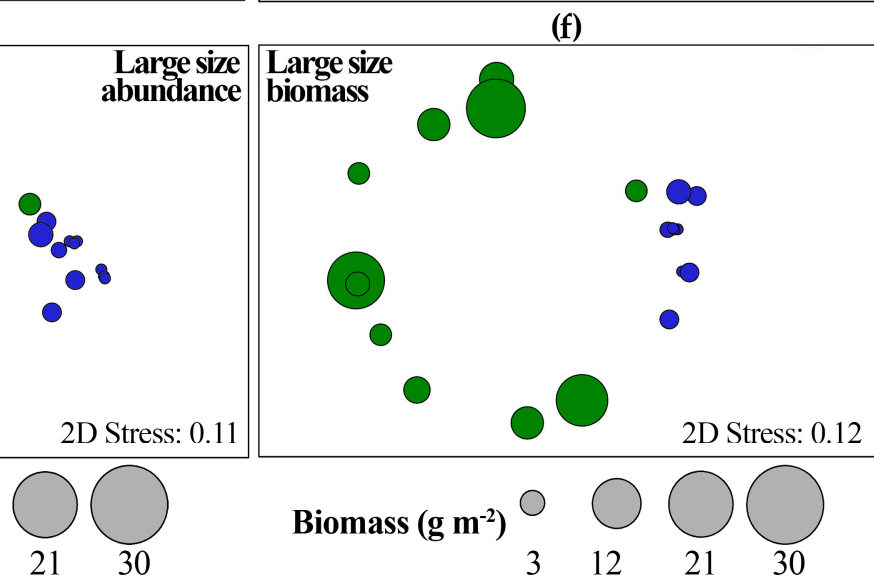

Figure 2. Non-metric multidimensional scaling (NMDS) plots of parrotfish abundance and biomass at sites at Serranilla and at San Andrés. Plots of abundance are shown for (a) all parrotfish, (c) smallsize parrotfish $(<50 \mathrm{~cm})$, and $(\mathbf{e})$ large-size parrotfish $(>50.1 \mathrm{~cm})$. Corresponding plots of biomass are shown for (b) all parrotfish, (d) small-size parrotfish, and (f) large-size parrotfish. Bubble sizes indicate the abundance or biomass values for each site. 


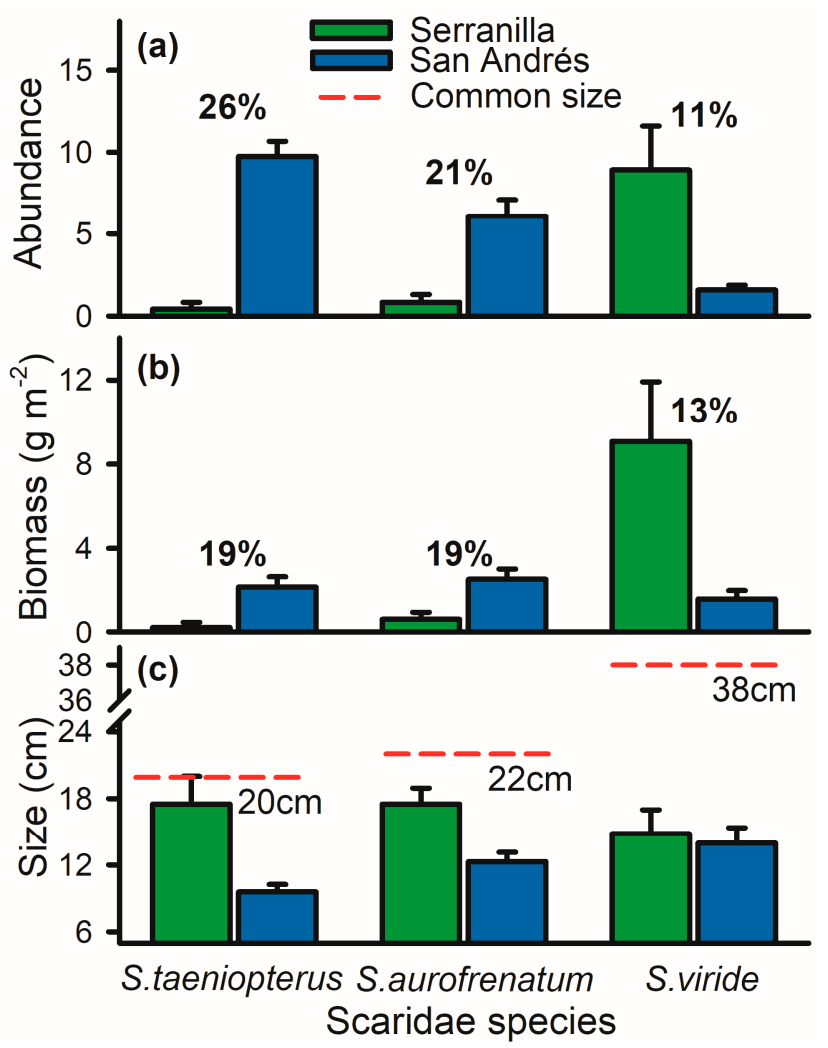

Figure 3. Comparison of mean (a) abundance, (b) biomass, and (c) size at Serranilla and at San Andrés of the three Scaridae species that together contribute at least $50 \%$ to the accumulated dissimilarity between these two study areas, as estimated by the SIMPER analysis. The contributions of the individual species are shown adjacent to the bars in (b). The error bars are \pm SE. The red lines and written values in the lower part indicate the common size of each species, as reported from FishBase [38].

\section{Discussion}

Our study demonstrates that variation in reef fish diversity, biomass, and abundance in Serranilla can be partly explained by two benthic components, coral cover and rugosity, that contribute to habitat complexity in coral reefs $[18,19]$. Nevertheless, the mean values of parrotfish biomass and length at Serranilla were low, which could reflect the effect of anthropogenic pressure in the area, mainly through illegal fishing [30-32].

Structural complexity in coral reefs has been evaluated for its ecological relevance, enhancing abundance, biomass, and biodiversity $[47,48]$. Multiple studies have found that the complexity of healthy coral reefs favors coastal protection, reducing the effects of wave action and other environmental phenomena and maintaining shoreline equilibrium $[9,49,50]$. A relationship of fish assemblage with the structural complexity, such as we observed at Serranilla in the Seaflower BR, has also been observed at other locations in the Atlantic [51,52] and in other regions of the world [53,54].

Reef habitat structures provide microhabitats and refuge areas that benefit multiple organisms, including reef fish $[55,56]$, with different rugosity levels favoring multiple fish groups [52]. Loss of habitat complexity can negatively affect multiple species [47,57], including reef fish [58], leading to species losses [11] and localized extinctions [59], including species of commercial interest such as parrotfish. Rogers et al. [52] predicted that a loss of complexity could cause a more than three-fold reduction in fishery productivity. Therefore, preserving complexity in coral reefs is crucial, particularly since structural complexity is currently in rapid decline in the Caribbean [17], with one of the largest protected areas in the Caribbean, the Seaflower BR, remaining highly vulnerable to anthropogenic pressure [33]. 
Coral reef degradation may also result from the loss of critical groups, such as the parrotfish. Their loss, through increased in macroalgae, decreased coral cover, and subsequently a diminished habitat complexity, may lead to a decline in associated organisms $[22,60]$. At Serranilla it was found that transects closer to Beacon Cay showed lower rugosity and diversity of reef fish. Although greater habitat complexity may have helped maintain higher abundance and biomass on Serranilla's reefs compared with those on San Andrés, direct anthropogenic pressure may still limit any positive effect, and lead to a lower abundance and diversity of reef fish, including parrotfish [22,46,47,52].

Anthropogenic pressure is among the most recurrent threats to coastal ecosystems, since human populations reside nearby and depend on coastal areas for commerce and survival $[61,62]$. Studies have found a relationship between reef fish assemblages and the distance from dense human populations [63], and found that sites closer to human populations tend to have lower abundance, biomass, and richness of reef fish than areas that are more remote, with an exponential increase in reef fish biomass as the distance from the significant human population increases [64,65].

Considering that Serranilla is far from any significant human population, we expected to find higher biomasses of reef fish, particularly of key coral reef groups such as the parrotfish. Beacon Cay, Serranilla, has only around 12 permanent inhabitants (equivalent to 9.2 inhabitants per $0.1 \mathrm{~km}^{2}$ ), while San Andrés has more than 65,000 (equivalent to 241 inhabitants per $0.1 \mathrm{~km}^{2}$ [33]. Additionally, more than 730,000 tourists visit San Andrés each year [65]. However, our data showed that despite the high reef rugosity, most parrotfish at Serranilla had low biomass and abundance values, similar to those found at San Andrés.

Differences in the size and abundance of some parrotfish species between Serranilla and San Andrés seem likely due to a lower fishing pressure at Serranilla. Nevertheless, fishing pressure may have modified the parrotfish assemblages at Serranilla. On San Andrés, fishing is one of the most important commercial activities, and includes spearfishing targeting multiple parrotfish species, such as S. coeruleus, S. coelestinus, and S. guacamaia [66], that were rarely observed during this study. While permitted fishing activity is mainly artisanal, illegal vessels have been reported carrying tons of illegally caught parrotfish [67]. In addition, Bruckner [34] reported illegal fishing boats at Serranilla island during the "Global Reef Expedition" in 2011, and such boats were also observed during the present "Seaflower Research Expedition" in 2017. Fishers have in recent years expressed concern over the absence of large parrotfish in the lagoon as a result of overfishing [68].

Herbivorous fish biomass has been used as one of the indicators for evaluating reef health. In the report on Mesoamerican reefs by the Healthy Reefs Initiative, they recorded $270 \mathrm{~kg} \mathrm{ha}^{-1}$ of herbivorous fish on the healthier reefs compared with $83 \mathrm{~kg} \mathrm{ha}^{-1}$ on reefs in critical conditions [69]. In particular, a relationship has been reported between fishing pressure and parrotfish biomass and size, making parrotfish abundance a useful biological indicator of fishing pressure [63]. On a small island in the Caribbean, exploited reefs, with areas open to artisanal fisheries, were found to have a parrotfish biomass of around $320 \mathrm{~kg} \mathrm{ha}^{-1}$, with smaller parrotfish contributing most of this biomass $\left(\sim 200 \mathrm{~kg} \mathrm{ha}^{-1}\right)$.

We found that Serranilla BR had larger parrotfish than San Andrés, though the biomass in Serranilla BR was nevertheless lower $\left(143 \mathrm{~kg} \cdot \mathrm{ha}^{-1}\right)$ than those values reported from other Caribbean MPAs with adequate protection and low local human populations, in which parrotfish biomass values can exceed $500 \mathrm{~kg} \cdot \mathrm{ha}^{-1}$ [70]. In contrast, in areas with high local human population densities and inadequate protection, parrotfish biomass can be rapidly reduced to $50 \mathrm{~kg} \cdot \mathrm{ha}^{-1}$ or less [22,29]. However, other factors may also influence herbivorous fish abundance; for example, on the Alacranes reef, an MPA in the southern part of the Gulf of Mexico, where human activities are restricted, and fishing pressure is low, the values of parrotfish biomass were nevertheless relatively low $\left(\sim 58-128 \mathrm{~kg} \mathrm{~h}^{-1}\right)$, although the parrotfish present had larger sizes than those observed on Caribbean reefs [71].

As with many other species, small individuals have become a target of fisheries due to the loss of larger individuals and the decline of other commercial fish species 
more generally, leading to decreased sizes [67]. Parrotfish size is likely related to reef resilience $[23,57]$, since larger individuals can remove more algae from the reef and have more effect on benthic communities than smaller ones [24,29]. In the present study, we found that $90 \%$ of the parrotfish species at Serranilla had smaller mean sizes than the typical size reported in FishBase [38]. Notably, the observed mean size of $S$. viride and $S$. chrysopterum were both below the size at first maturity (L50), as recorded in the Colombian Caribbean [72], suggesting a higher fishing pressure at Serranilla than expected.

\section{Conclusions}

This study on Serranilla island, which is part of the Seaflower BR, has demonstrated that the overall reef fish assemblage is spatially variable with habitat structure explaining up to $66 \%$ of this variation [53,57]. In addition, focusing on the parrotfish and their sizes has allowed us to compare sizes and biomasses of fish on Serranilla with those on San Andrés. In combination, the results presented here, together with the intense illegal fishing activities observed in the reserve and other drivers not considered in this study, highlight the need to evaluate other factors that may influence reef fish biodiversity beyond structural complexity [26,73]. Meanwhile biological and ecological information about the current status of most of the key groups in the Seaflower BR remains scarce [67]. Maintaining healthy reef ecosystems is becoming critical, especially in areas where human well-being depends on coral reef ecosystem services, such as food production [73], so that the need for effective management and active surveillance at the Serranilla MPA is urgent.

Supplementary Materials: The following are available online at https: / www.mdpi.com/article / 10.3390/oceans2030034/s1, Figure S1: Serranilla Island and distances between islands (San Andres 415 km, Providencia 309 km, Jamaica 305 km), Figure S2: Mean observed fish sizes during census at Serranilla Island (SI) compared with the common and maximum (Max) reported in FishBase, Table S1: Site summary of the metrics of fish assemblages in Serranilla Island with average value per metric \pm SD, Table S2: Summary of fish assemblage families and species in Serranilla Island. Values of abundance and biomass with the total sum, frequency, and average \pm SD, Table S3: Summary of the abundance and biomass of the Scaridae species in Serranilla and San Andrés with the average values \pm SD, Table S4: SIMPER analysis summary. Scaridae average contribution and cumulative contribution percentage in biomass and abundance to the dissimilarity between SI and SAI. Registered and common length of those species.

Author Contributions: Conceptualization, D.C., D.M.-d.-A., J.P., A.L.C.-M. and A.S.-M.; Data curation, D.C., J.P. and J.P.E.; Formal analysis, D.C., D.M.-d.-A. and J.P.; Funding acquisition, A.S.-M., D.C. and J.P.; Investigation, D.C., D.M.-d.-A., J.P., A.L.C.-M. and A.S.-M.; Methodology, D.C., D.M.-d.-A., J.P., A.L.C.-M., J.P.E. and A.S.-M.; Supervision, A.L.C.-M. and A.S.-M.; Validation, A.L.C.-M. and A.S.-M.; Visualization, D.C., D.M.-d.-A., J.P. and J.P.E.; Writing-original draft, D.C., D.M.-d.-A., J.P. and A.L.C.-M.; Writing-review and editing, D.C., D.M.-d.-A., J.P., A.L.C.-M., J.P.E. and A.S.-M. All authors have read and agreed to the published version of the manuscript.

Funding: This research was developed thanks to the funding of the Universidad Nacional de Colombia Sede Caribe on the frame of Seaflower Research Expedition 2017, supported by multiple institutions, including essential contributions from Colombia BIO-Colciencias project and Colombian Ocean Commission (CCO), Project management contract No. FP4484-398-2015, Armada Nacional de Colombia, Corporación para el Desarrollo Sostenible del departamento (Coralina), Gobernación de San Andrés, Providencia y Santa Catalina, and Universidad Nacional de Colombia Sede Caribe. The project under which this research was conducted is "Valoración de servicios ecosistémicos de los arrecifes de coral en los alrededores de la Isla Cayo Serranilla, Reserva de Biosfera Seaflower, Caribe Colombiano," developed and supported by Universidad Nacional de Colombia Sede Caribe. Additional funding included Colciencias Ph.D. scholarship (Conv. 757) and CEMarin (Call 14, 2018) that funded the maintenance of the CEMarin young researcher Julián Prato and the project "Relationships between coral reef complexity and ecosystem services at Caribbean oceanic islands, Seaflower Biosphere Reserve, Colombia". Universidad Nacional de Colombia Sede Caribe funded fish census at San Andrés to Diana Castaño MSc. thesis project "Estructura y Función de peces herbívoros en zonas arrecifales de San Andrés una isla oceánica en el Caribe". 
Data Availability Statement: The datasets generated during the current study are available within the article and its supplementary materials. Additional data are available from the authors on reasonable request.

Acknowledgments: We express our special thanks to the Universidad Nacional de Colombia Sede Caribe for supporting our participation in the Seaflower Research Expedition 2017 "Cayos de Serranilla Island." We thank Armada Nacional de Colombia, Corporación para el Desarrollo Sostenible del Archipiélago de San Andrés, Providencia y Santa Catalina (Coralina), Nacor Bolaños, the crew of the ARC 20 de Julio vessel and Captain and fisherman Casimiro Newball for their support during sailing and sampling at the expedition. We also thank personnel from the Colombian Ocean Commission (CCO) specially to VALM Juan Manuel Soltau, CF Hurtado, CN. Guerra and Juliana Sintura for their important work to make the expedition possible. Finally, we thank Venus Avendaño and Alicia del Mar PC for their multiple support and Omar Abril Howard, Brigitte Gavio, and Violeta Posada for contributing to a successful field working team. We also thank two anonymous referees and the Special Issue editor for their great assistance in improving the manuscript.

Conflicts of Interest: The authors declare no conflict of interest. The funders had no role in the design of the study; in the collection, analyses, or interpretation of data; in the writing of the manuscript, or in the decision to publish the results.

\section{References}

1. Moritz, C.; Vii, J.; Lee Long, W.; Tamelander, J.; Thomassin, A.; Planes, S. Status and Trends of Coral Reefs of the Pacific. In Global Coral Reef Monitoring Network; Technical Report; United Nations Environment Programme: Washington, DC, USA, 2018; pp. 47-50.

2. Komyakova, V.; Munday, P.L.; Jones, G.P. Relative Importance of Coral Cover, Habitat Complexity and Diversity in Determining the Structure of Reef Fish Communities. PLoS ONE 2013, 8, e83178. [CrossRef] [PubMed]

3. Knowlton, N.; Brainard, R.E.; Fisher, R.; Moews, M.; Plaisance, L.; Caley, M.J. Coral reef biodiversity. In Life in the World's Oceans: Diversity Distribution and Abundance, 1st ed.; McIntyre; Blackwell Publishing Ltd.: West Sussex, UK, 2010 ; pp. 65-78.

4. Plaisance, L.; Caley, M.J.; Brainard, R.E.; Knowlton, N. The diversity of coral reefs: What are we missing? PLoS ONE 2011, 6, e25026. [CrossRef] [PubMed]

5. Woodhead, A.J.; Hicks, C.C.; Norström, A.V.; Williams, G.J.; Graham, N.A.J. Coral reef ecosystem services in the Anthropocene. Funct. Ecol. 2019, 33, 1023-1034. [CrossRef]

6. Costanza, R.; de Groot, R.; Sutton, P.; van der Ploeg, S.; Anderson, S.J.; Kubiszewski, I.; Farber, S.; Turner, R.K. Changes in the Global Value of Ecosystem Services. Glob. Environ. Chang. 2014, 26, 152-158. [CrossRef]

7. Waite, R.; Burke, L.; Gray, E. Coastal Capital: Ecosystem Valuation for Decision Making in the Caribbean; World Resources Institute: Washington, DC, USA, 2014; pp. 1-78.

8. Elliff, C.I.; Silva, I.R. Coral Reefs as the First Line of Defense: Shoreline Protection in Face of Climate Change. Mar. Environ. Res. 2017, 127, 148-154. [CrossRef]

9. Reguero, B.G.; Beck, M.W.; Agostini, V.N.; Kramer, P.; Hancock, B. Coral Reefs for Coastal Protection: A New Methodological Approach and Engineering Case Study in Grenada. J. Environ. Manag. 2018, 210, 146-161. [CrossRef]

10. Samonte-Tan, G.P.B.; White, A.T.; Tercero, M.A.; Diviva, J.; Tabara, E.; Caballes, C. Economic Valuation of Coastal and Marine Resources: Bohol Marine Triangle, Philippines. Coast. Manag. 2007, 35, 319-338. [CrossRef]

11. Hughes, T.P.; Baird, A.H.; Bellwood, D.R.; Card, M.; Connolly, S.R.; Folke, C.; Grosberg, R.; Hoegh-Guldberg, O.; Jackson, J.B.C.; Kleypas, J.; et al. Climate Change, Human Impacts, and the Resilience of Coral Reefs. Science 2003, 301, 929-933. [CrossRef]

12. Burke, L.; Spalding, M.D.; Perry, A. Reefs at Risk Revisited; World Resources Institute: Washington, DC, USA, $2011 ;$ p. 114.

13. Pandolfi, J.M.; Connolly, S.R.; Marshall, D.J.; Cohen, A.L. Projecting Coral Reef Futures under Global Warming and Ocean Acidification. Science 2011, 333, 418-422. [CrossRef]

14. Gardner, T.A.; Côté, I.M.; Gill, J.A.; Grant, A.; Watkinson, A.R. Long-Term Region-Wide Declines in Caribbean Corals. Science 2003, 301, 958-960. [CrossRef]

15. Burke, L.; Maidens, J. Reefs at Risk in the Caribbean; World Resources Institute: Washington, DC, USA, 2004; p. 80.

16. Mumby, P.J.; Wolff, N.H.; Bozec, Y.M.; Chollett, I.; Halloran, P. Operationalizing the Resilience of Coral Reefs in an Era of Climate Change. Conserv. Lett. 2014, 7, 176-187. [CrossRef]

17. Álvarez-Filip, L.; Dulvy, N.K.; Gill, J.A.; Côté, I.M.; Watkinson, A.R. Flattening of Caribbean Coral Reefs: Region-Wide Declines in Architectural Complexity. Proc. Royal Soc. B 2009, 276, 3019-3025. [CrossRef] [PubMed]

18. Álvarez-Filip, L.; Carricart-Ganivet, J.P.; Horta-Puga, G.; Iglesias-Prieto, R. Shifts in Coral-Assemblage Composition Do Not Ensure Persistence of Reef Functionality. Sci. Rep. 2013, 3, 1-15. [CrossRef] [PubMed]

19. Zea, S.; Geister, J.; Garzón-Ferreira, J.; Díaz, J.M. Biotic Changes in the Reef Complex of San Andres Island (Southeastern Caribbean Sea, Columbia) Occuring over Three Decades. Atoll. Res. Bull. 1998, 456, 1-30. [CrossRef]

20. Guannel, G.; Arkema, K.; Ruggiero, P.; Verutes, G. The Power of Three: Coral Reefs, Seagrasses and Mangroves Protect Coastal Regions and Increase Their Resilience. PLoS ONE 2016, 11, e0158094. [CrossRef] [PubMed] 
21. Pendleton, L.H.; Hoegh-Guldberg, O.; Langdon, C.; Comte, A. Multiple Stressors and Ecological Complexity Require a New Approach to Coral Reef Research. Front. Mar. Sci. 2016, 3, 36. [CrossRef]

22. Mumby, P.J. The impact of exploiting grazers (Scaridae) on the dynamics of Caribbean coral reefs. Ecol. Appl. 2006, 16, 747-769. [CrossRef]

23. Jackson, J.; Donovan, M.; Cramer, K.; Lam, V. Status and Trends of Caribbean Coral Reefs; Global Coral Reef Monitoring Network: Washington, DC, USA, 2014; p. 304.

24. Jackson, J.B.C. Reefs since Columbus. Coral Reefs 1997, 16, S23-S32. [CrossRef]

25. Carpenter, R.C. Mass Mortality of Diadema Antillarum II. Effects on Population Densities and Grazing Intensity of Parrotfishes and Surgeonfishes. Mar. Biol. 1990, 104, 79-86. [CrossRef]

26. Burkepile, D.E.; Hay, M.E. Herbivore Species Richness and Feeding Complementarity Affect Community Structure and Function on a Coral Reef. Proc. Natl. Acad. Sci. USA 2008, 105, 16201-16206. [CrossRef]

27. Adam, T.C.; Schmitt, R.J.; Holbrook, S.J.; Brooks, A.J.; Edmunds, P.J.; Carpenter, R.C.; Bernardi, G. Herbivory, Connectivity, and Ecosystem Resilience: Response of a Coral Reef to a Large-Scale Perturbation. PLoS ONE 2011, 6, e23717. [CrossRef] [PubMed]

28. Mumby, P.J.; Dahlgren, C.P.; Harborne, A.R.; Kappel, C.V.; Micheli, F.; Brumbaugh, D.R.; Holmes, K.E.; Mendes, J.M.; Broad, K.; Sanchirico, J.N.; et al. Fishing, Trophic Cascades, and the Process of Grazing on Coral Reefs. Science 2006, 311, 98-101. [CrossRef]

29. Bonaldo, R.; Hoey, A.; Bellwood, D. The Ecosystem Roles of Parrotfishes on Tropical Reefs. Oceanogr. Mar. Biol. Annu. Rev. 2014, $52,81-132$.

30. Bellwood, D.R.; Hughes, T.P.; Folke, C.; Nyströ, M. Confronting the Coral Reef Crisis. Nature 2004, 429, 827-833. [CrossRef]

31. Hawkins, J.P.; Roberts, C.M. Effects of Artisanal Fishing on Caribbean Coral Reefs. Conserv. Biol. 2004, 18, 215-226. [CrossRef]

32. Bozec, Y.M.; O'Farrell, S.; Bruggemann, J.H.; Luckhurst, B.E.; Mumby, P.J. Tradeoffs between Fisheries Harvest and the Resilience of Coral Reefs. Proc. Natl. Acad. Sci. USA 2016, 113, 4536-4541. [CrossRef] [PubMed]

33. Gómez-López, D.I.; Segura-Quintero, C.; Sierra-Correa, P.C.; Garay-Tinoco, J. Atlas de La Reserva de Biósfera Seaflower. Archipiélago de San Andrés, Providencia y Santa Catalina; Serie de Publicaciones Especiales; INVEMAR: Bogotá, Colombia, $2012 ;$ p. 180.

34. Bruckner, A. Global Reef Expedition: San Andrés Archipelago, Colombia; Field Report; Khaled bin Sultan Living Oceans Foundation: Landover, MD, USA, 2012; p. 52.

35. Samoilys, M.A.; Carlos, G. Determining Methods of Underwater Visual Census for Estimating the Abundance of Coral Reef Fishes. Environ. Biol. Fishes 2000, 57, 289-304. [CrossRef]

36. World Wild Fund (WWF). Mejores prácticas de pesca en arrecifes coralinos. In Guía para la Colecta de Información que Apoye el Manejo de Pesquerías Basado en Ecosistemas; WWF: Cancún, México; San José, Costa Rica, 2006; p. 81.

37. Caldwell, Z.R.; Zgliczynski, B.J.; Williams, G.J.; Sandin, S.A. Reef Fish Survey Techniques: Assessing the Potential for Standardizing Methodologies. PLoS ONE 2016, 11, e0153066. [CrossRef]

38. Froese, R.; Pauly, D. Fish Base. World Wide Web Electronic Publication. Available online: www.fishbase.org (accessed on 12 December 2019).

39. Fricke, R.; Eschmeyer, W.N.; Fong, J.D. Species by Family/Subfamily. Eschmeyer's Catalog of Fishes. Available online: www.researcharchive.calacademy.org/research/ichthyology/catalog/SpeciesByFamily.asp (accessed on 21 December 2019).

40. Risk, M.J. Fish Diversity on a Coral Reef in the Virgin Islands. Atoll. Res. Bull. 1972, 153, 1-6. [CrossRef]

41. Jost, L. Entropy and Diversity. Oikos 2006, 113, 363-375. [CrossRef]

42. Burnham, K.P.; Anderson, D.R. Multimodel inference: Understanding AIC and BIC in model selection. Sociol. Methods Res. 2004, 33, 261-304. [CrossRef]

43. Zar, J.H. Biostatistical Analysis, 5th ed.; Pearson Prentice-Hall: New Jersey, NJ, USA, 2010; p. 944.

44. Anderson, M.; Gorley, R.; Clarke, K.P. For PRIMER: Guide to Software and Statistical Methods; PRIMER-E: Plymouth, UK, 2008.

45. Clarke, K.R.; Gorley, R.N. Primer v6 Permanova+; PRIMER-E: Plymouth, UK, 2006.

46. Team, R. A Language and Environment for Statistical Computing; R Foundation for Statistical Computing: Vienna, Austria, 2018.

47. Harborne, A.R.; Mumby, P.J.; Ferrari, R. The Effectiveness of Different Meso-Scale Rugosity Metrics for Predicting Intra-Habitat Variation in Coral-Reef Fish Assemblages. Environ. Biol. Fishes 2012, 94, 431-442. [CrossRef]

48. Richardson, L.E.; Graham, N.A.J.; Pratchett, M.S.; Hoey, A.S. Structural Complexity Mediates Functional Structure of Reef Fish Assemblages among Coral Habitats. Environ. Biol. Fishes 2017, 100, 193-207. [CrossRef]

49. Van Zanten, B.T.; van Beukering, P.J.H.; Wagtendonk, A.J. Coastal Protection by Coral Reefs: A Framework for Spatial Assessment and Economic Valuation. Ocean Coast. Manag. 2014, 96, 94-103. [CrossRef]

50. Monismith, S.G.; Rogers, J.S.; Koweek, D.; Dunbar, R.B. Frictional Wave Dissipation on a Remarkably Rough Reef. Geophys. Res. Lett. 2015, 42, 4063-4071. [CrossRef]

51. Walker, B.K.; Jordan, L.K.B.; Spieler, R.E. Relationship of Reef Fish Assemblages and Topographic Complexity on Southeastern Florida Coral Reef Habitats. J. Coast. Res. 2009, 53, 39-48. [CrossRef]

52. Rogers, A.; Blanchard, J.L.; Mumby, P.J. Vulnerability of Coral Reef Fisheries to a Loss of Structural Complexity. Curr. Biol. 2014, 24, 1000-1005. [CrossRef] [PubMed]

53. Friedlander, A.M.; Parrish, J.D. Habitat Characteristics Affecting Fish Assemblages on a Hawaiian Coral Reef. J. Exp. Mar. Biol. Ecol. 1998, 224, 1-30. [CrossRef] 
54. González-Rivero, M.; Harborne, A.R.; Herrera-Reveles, A.; Bozec, Y.M.; Rogers, A.; Friedman, A.; Ganase, A.; Hoegh-Guldberg, O. Linking Fishes to Multiple Metrics of Coral Reef Structural Complexity Using Three-Dimensional Technology. Sci. Rep. 2017, 7, $1-15$.

55. Kuffner, I.B.; Brock, J.C.; Grober-Dunsmore, R.; Bonito, V.E.; Hickey, T.D.; Wright, C.W. Relationships between Reef Fish Communities and Remotely Sensed Rugosity Measurements in Biscayne National Park, Florida, USA. Environ. Biol. Fishes 2007, 78, 71-82. [CrossRef]

56. Graham, N.A.J.; Nash, K.L. The Importance of Structural Complexity in Coral Reef Ecosystems. Coral Reefs 2013, 32, 315-326. [CrossRef]

57. Plass-Johnson, J.G.; Ferse, S.C.A.; Jompa, J.; Wild, C.; Teichberg, M. Fish Herbivory as Key Ecological Function in a Heavily Degraded Coral Reef System. Limnol. Oceanogr. 2015, 60, 1382-1391. [CrossRef]

58. Paddack, M.J.; Reynolds, J.D.; Aguilar, C.; Appeldoorn, R.S.; Beets, J.; Burkett, E.W.; Chittaro, P.M.; Clarke, K.; Esteves, R.; Fonseca, A.C.; et al. Dynamic Fragility of Oceanic Coral Reef Ecosystems. Proc. Natl. Acad. Sci. USA 2006, 103, 8425-8429.

59. Pratchett, M.S.; Munday, P.; Wilson, S.K.; Graham, N.A.; Cinner, J.E.; Bellwood, D.R.; Jones, G.P.; Polunin, N.V.; McClanahan, T.R. Effects of Climate-Induced Coral Bleaching on Coral-Reef Fishes. Ecological and economic consequences. Oceanogr. Mar. Bio Annu. Rev. 2008, 46, 251-296.

60. Jackson, J.B.C.; Kirby, M.X.; Berger, W.H.; Bjorndal, K.A.; Botsford, L.W.; Bourque, B.J.; Bradbury, R.H.; Cooke, R.; Erlandson, J.; Estes, J.A. Historical Overfishing and the Recent Collapse of Coastal Ecosystems. Science 2001, 293, 629-637. [CrossRef] [PubMed]

61. Pandolfi, J.M.; Bradbury, R.H.; Sala, E.; Hughes, T.P.; Bjorndal, K.A.; Cooke, R.G.; McArdle, D.; McClenachan, L.; Newman, M.J.H.; Paredes, G.; et al. Global Trajectories of the Long-Term Decline of Coral Reef Ecosystems. Science 2003, 301, 955-958. [CrossRef] [PubMed]

62. Vallès, H.; Gill, D.; Oxenford, H.A. Parrotfish Size as a Useful Indicator of Fishing Effects in a Small Caribbean Island. Coral Reefs 2015, 34, 789-801. [CrossRef]

63. Cinner, J.E.; Graham, N.A.J.; Huchery, C.; Macneil, M.A. Global Effects of Local Human Population Density and Distance to Markets on the Condition of Coral Reef Fisheries. Conserv. Biol. 2013, 27, 453-458. [CrossRef]

64. Brewer, T.D.; Cinner, J.E.; Fisher, R.; Green, A.; Wilson, S.K. Market Access, Population Density, and Socioeconomic Development Explain Diversity and Functional Group Biomass of Coral Reef Fish Assemblages. Glob. Environ. Chang. 2012, 22, 399-406. [CrossRef]

65. Prato, J.A.; Newball, R. Aproximación a La Valoración Económica Ambiental Del Departamento Archipiélago de San Andrés, Providencia y Santa Catalina; Comisión Colombiana del Océano: Bogotá, Colombia, 2016.

66. Chasqui, V.; Polanco, L.A.; Acero, A.; Mejía-Falla, P.A.; Navia, A.; Zapata, L.A.; Caldas, J.P. Libro Rojo de Peces Marinos de Colombia; Instituto de Investigaciones Marinas y Costeras Invemar, Ministerio de Ambiente y Desarrollo Sostenible: Santa Marta, Colombia, 2017; p. 552.

67. Friedlander, A.; Nowlis, J.S.; Sanchez, J.A.; Appeldoorn, R.; Usseglio, P.; Mccormick, C.; Bejarano, S.; Mitchell-Chui, A. Designing Effective Marine Protected Areas in Seaflower Biosphere Reserve, Colombia, Based on Biological and Sociological Information. Conserv. Biol. 2003, 17, 1769-1784. [CrossRef]

68. McField, M.; Kramer, P.; Giró Petersen, A.; Soto, M.; Drysdale, I.; Craig, N.; Rueda-Flores, M. Mesoamerican Reef Report Card, Healthy Reefs Initiative. Available online: www.healthyreef.org (accessed on 28 June 2021).

69. Bruggemann, J.H.; van Rooij, J.M.; Videler, J.J.; Breeman, A.M. Dynamics and Limitations of Herbivore Populations on a Caribbean Coral Reef. Ph.D. Thesis, University of Groningen, Groningen, The Netherlands, 1995.

70. Hernández-Landa, R.C.; Aguilar-Perera, A. Structure and composition of surgeonfish (Acanthuridae) and parrotfish (Labridae: Scarinae) assemblages in the south of the Parque Nacional Arrecife Alacranes, southern Gulf of Mexico. Mar. Biol. 2019, 49, 647-662. [CrossRef]

71. Jaimes Rodríguez, L.I. Algunos Aspectos Biológico-Pesqueros de Las Principales Especies Ícticas Capturadas En El Sector de San Bernardo, Parque Nacional Natural Corales Del Rosario y de San Bernardo, Caribe Colombiano. Bachelor's Thesis, Universidad de Bogotá Jorge Tadeo Lozano, Bogotá, Colombia, 2011.

72. McClanahan, T.; Karnauskas, M. Relationships between Benthic Cover, Current Strength, Herbivory, and a Fisheries Closure in Glovers Reef Atoll, Belize. Coral Reefs 2011, 30, 9-19. [CrossRef]

73. Balzan, M.V.; Caruana, J.; Zammit, A. Assessing the Capacity and Flow of Ecosystem Services in Multifunctional Landscapes: Evidence of a Rural-Urban Gradient in a Mediterranean Small Island State. Land Use Policy 2018, 75, 711-725. [CrossRef] 